\title{
Arbuscular Mycorrhizal Assessment of Ornamental Trees Grown in Tennessee Field Soils
}

\author{
W.E. Klingeman ${ }^{1}$, R.M. Augé ${ }^{2}$, and P.C. Flanagan ${ }^{3}$ \\ University of Tennessee, Institute of Agriculture, Plant Sciences and Landscape \\ Systems, 2431 Center Drive, 252 Ellington Plant Science Building, Knoxville, \\ TN 37996-4500
}

Additional index words. red maple, Acer rubrum, flowering dogwood, Cornus florida, Kwanzan cherry, Prunus serrulata

Abstract. Mycorrhizal symbiosis, a natural association between roots and certain soil fungi, can improve growth and increase stress resistance of many nursery crops. Field soils of four middle Tennessee and two eastern Tennessee nurseries were surveyed for their mycorrhizal inoculum potential (MIP), phosphorus (P) and potassium (K) concentrations, and soil pH. Arbuscular mycorrhizal (AM) fungi, which colonized seedlings of a Sorghum bicolor trap-crop, were recovered from all soils. Tissue samples were taken from young roots of three economically important tree species grown in nursery field soils: red maple (Acer rubrum L. 'October Glory'), flowering dogwood (Cornus florida L. 'Cherokee Princess'), and Kwanzan cherry (Prunus serrulata Lindl. 'Kwanzan'). AM fungi, regardless of soil type, soil $\mathrm{pH}$, or $\mathrm{P}$ or $\mathrm{K}$ concentration, had colonized young roots of all three species. Unless interested in establishing exotic mycorrhizae, ornamental nursery producers in Tennessee do not need to supplement field soils with these beneficial fungi.

Arbuscular mycorrhizal fungi are beneficial soil-inhabiting fungi that establish natural symbiotic associations within roots of native and crop plants. AM fungi coexist within the extracellular spaces of living root cortical tissues and enable the host plant to increase water, phosphorus, nitrogen, and micronutrient uptake under some circumstances (Bethlenfalvay, 1992; Brundrett, 1991; Kling and Jakobsen, 1998). The benefits of AM fungi are most evident in nutrient-depleted or structurally damaged soils. However, in field and laboratory tests, several ornamental and crop plants colonized by AM fungi have demonstrated increased advantages overnon-colonized plants. Advantages include drought tolerance, reduced pathogen pressure, activation of plant defense mechanisms, increased growth, and general benefits to plant health (Augé et al., 1987, 1995; Azcon-Aguilar and Barea, 1996; Brundrett, 1991; Duan et al., 1996). AM fungi also enhance soil aggregation and water-holding capacity both by producing hyphae external to the host plant root tissues and by exuding glomalin, a glycoprotein, from extraradical hyphae (Wright and Upadhyaya, 1998).

In ornamental nursery field soils, where plants may receive regular fertilization and water, the benefits of AM fungi to plant performance are not well defined. Many practices common in field production reduce crop colonization and may potentially eliminate AM fungal populations, particularly since spores

Received for publication 2 Apr. 2001. Accepted for publication 13 Nov. 2001.

${ }^{1}$ Assistant Professor.

${ }^{2}$ Professor

${ }^{3}$ Research Associate. and hyphae of most AM fungi occur within the top $20.0 \mathrm{~cm}$ (7.9 inches) of soil (Abbott and Robson, 1991). Tillage of soil disrupts extraradical hyphae requiring hyphal regrowth or resting spore germination for colonization of crop root tissues (Abbott and Robson, 1991; Miller et al., 1995). Crop rotations may include ornamental plant species not readily colonized by AM fungi that, paired with fallow periods in the nursery fields, further reduce AM populations (Abbott and Robson, 1991; Bethlenfalvay, 1992; Kling and Jakobsen, 1998). Mycorrhizal associations have also been reduced in some host plants when fertilizers, particularly phosphate, are heavily applied (Abbott and Robson, 1991; Brundrett, 1991; Collins-Johnson and Pfleuger, 1992; Jakobsen, 1986; Miller et al., 1995). Research on mycorrhizal responses to fertilization, which have demonstrated both increases and reductions in mycorrhizal activity, suggests that mycorrhizae may become acclimated to soil fertility (Collins-Johnson and Pfleuger, 1992; Hayman, 1982). Nursery field soils are also susceptible to direct and runoff applications of pesticide sprays that are used to control plant pests and diseases. Benomyl, once used extensively in nursery production, and carbendazim fungicides have been identified as the most harmful fungicides to AM function and survival (Kling and Jacobsen, 1997; Larsen et al., 1996).

The presence and degree of AM associations occurring naturally under ornamental nursery production conditions have not been adequately addressed. Still, benefits of mycorrhizal inoculation of ornamental plants are aggressively marketed for all types of nursery production. The objectives of this research address two fundamental questions: Do soils in Tennessee's ornamental production areas currently contain populations of AM fungi? Are AM fungi forming active associations with commonly grown and economically important trees that are grown in Tennessee?

\section{Materials and Methods}

In Nov. 1999, undisturbed soil cores and root and soil samples were collected from production areas surrounding field-grown trees at four middle Tennessee nurseries and two eastern Tennessee nurseries. Two nurseries were located within each of three USDANRCS soil area zones: Laurels Nursery (Hampton, Tenn., $\left.36^{\circ} 17^{\prime} \mathrm{N}, 82^{\circ} 10^{\prime} \mathrm{W}\right)$ and Fairview Tree Farm (Piney Grove, Tenn., 36 $13^{\prime} \mathrm{N}$, $82^{\circ} 14^{\prime} \mathrm{W}$ ) were situated in Blue Ridge (BR) soils; Odom Nursery (Morrison, Tenn., $35^{\circ} 36^{\prime} \mathrm{N}, 85^{\circ} 37^{\prime} \mathrm{W}$ ) and Hawkersmith and Sons' Nursery (Hickerson Station, Tenn., $\left.35^{\circ} 21^{\prime} \mathrm{N}, 86^{\circ} 12^{\prime} \mathrm{W}\right)$ were in Highland Rim and Pennyroyal (HRP) soils; and Pleasant Cove Nursery (Rock Island, Tenn., $36^{\circ} 17^{\prime} \mathrm{N}$, $85^{\circ} 37^{\prime} \mathrm{W}$ ) and Little River Nursery (Tarlton, Tenn., $35^{\circ} 30^{\prime} \mathrm{N}, 85^{\circ} 39^{\prime} \mathrm{W}$ ) soils were typical of Cumberland Plateau and Mountain (CPM) regional physiography (USDA-NRCS, 2001). Soils within each zone were also provided soil taxonomic classifications (Table 1). Tissue samples of young roots were collected from three ornamental tree species that are economically important to Tennessee nursery production: red maple (Acer rubrum 'October Glory'), flowering dogwood (Cornus florida 'Cherokee Princess'), and Kwanzan cherry (Prunus serrulata 'Kwanzan'). At each nursery, five trees per cultivar were sampled within 15- to 20-m-long sections in production rows. Tree calipers were measured $15.2 \mathrm{~cm}$ above the soil line and fine-root samples were collected from a 30.5 -cm-deep hole dug $\approx 35 \mathrm{~cm}$ from the bole of each tree. Tissue samples were labeled, placed in a cooler, and transported to the Univ. of Tennessee Institute of Agriculture(UTIA) research facilities in Knoxville for analysis.

A composite soil sample, which consisted of 20 subsample units collected within the crop production rows, was taken for each ornamental cultivar at each nursery. The Univ. of Tennessee Soil Testing Laboratory in Nashville analyzed the soil samples for soil $\mathrm{pH}$, soluble salts, potassium, and phosphorus concentrations using Melich-1 extraction. To assess the mycorrhizal inoculum potential (MIP) of the nursery production soils, a $5.7 \times 5.7 \mathrm{~cm}$ modified soil corer was used to gather five 17.8 -cm-deep soil cores, within the production rows, from each crop at each nursery. Thus, sampling minimally disturbed the soil cores. Soil cores were placed in a $6.0 \times 6.0 \mathrm{~cm}$ $\times 12.7 \mathrm{~cm}$ band pot (Anderson Die and Mfg., Portland, Ore.), the top $5.1 \mathrm{~cm}$ of field soil was removed, and cores were transported to Knoxville, Tenn. During the collection of soil cores, a thermometer was inserted into the soil of the production rows and soil temperature recorded at a depth of $22.9 \mathrm{~cm}$.

In a UTIA greenhouse, three Sorghum bicolor (L.) Moench. 'DeKalb DK40Y' 
(Monsanto Co., St. Louis) seeds were planted into the undisturbed soil cores and were maintained at $24 \pm 3{ }^{\circ} \mathrm{C}$ with a 16 -h light $/ 8$-h dark photoperiod. Sorghum roots are readily colonized by many non-host-specific AM fungi and can be easily cleared and stained to reveal AM-fungal structures. Sorghum is frequently used to maintain pot cultures of AM fungi. Treated sorghum seed coats were wetted and wiped free of excess Captan 50 WP fungicide (Micro Flo Co., Lakeland, Fla.). Seedlings were grown for 10 weeks, after which roots were carefully washed free of soil and sampled. In the laboratory, both $S$. bicolor and tree roots were washed then cleared using a $10 \% \mathrm{KOH}$ solution followed by a $3 \%$ solution of hydrogen peroxide. To enhance staining intensity, root samples were acidified using $0.5 \mathrm{M} \mathrm{HCL}$. Roots were stained using $0.05 \%$ Trypan blue in lactoglycerol. Finally, roots were kept in lactoglycerol destaining solution until two slides of stained root tissues per sample could be prepared (Brundrett, 1991). About twentyfive $1-\mathrm{cm}$-long root sections were mounted per slide. Using a light microscope, stained roots were examined for the presence of AM fungi. Percentage of roots colonized was quantified by counting cross-hair intersections among 100 fields-of-view using a stereoscopic microscope (100×) (McGonigle et al., 1990). Intersections were scored with the number of vesicles, arbuscules, and hyphae observed.

Influence of tree species and soil zone on root colonization and MIP was analyzed using a mixed ANOVA in SAS, with nursery nested within soil zones (SAS Institute, 1985). Occurrence of fungal structures was also contrasted between soil zones. Means were sepa- rated using an LSD value $(P \leq 0.05)$. Correlation coefficients were calculated for data pooled among nurseries using the PROC CORR procedure in SAS (SAS Institute, 1985). Correlation analyses investigated the relationship of soil $\mathrm{pH}$, trunk size, soil phosphorus, and soil potassium to AM fungal structures, in both tree root samples and the MIP test with sorghum. Correlation analysis was also used to test the relationship between the number of fungal structures in tree root samples and the number of fungal structures in sorghum root samples from the MIP test.

\section{Results and Discussion}

AM fungal associations have been described in ornamental maples (Acer sp.) (Brechet and le Tacon, 1984; Spiess et al., 1991), Prunus genera, such as peaches (Prunus persica L.) (McGraw and Schenck, 1980) and sandcherry (Prunus $\times$ cistena N.E. Hansen) (Morrison et al., 1993), and have been recovered from roots of flowering dogwood (Cornus florida L.) (Sylvia, 1986). In this study, roots were sampled from 1- to 4-year-old A. rubrum 'October Glory', C. florida 'Cherokee Princess', and $P$. serrulata 'Kwanzan' trees grown in nursery field soils. Trees presented a range of trunk diameters correlated with age (data not shown). Regardless of tree age or caliper of the trees, only young, fine roots were sampled. These rootlets, which are continuously regenerated, provide ready inoculation points for AM fungi and are generally the only root tissues colonized (Brundrett, 1991; Reynolds, 1975).

Examination of stained roots revealed both fungal hyphae and vesicles, and arbuscules, which are specific to AM fungi, in the young root tissue of all three tree species (Table 2). Hyphae were generally abundant in all samples. Vesicles, the storage and possibly propagative structures of mycorrhizal fungi, were less common. Arbuscules were observed in tree roots taken from all nurseries except Fairview Nursery in the BR soils of eastern Tennessee, where only hyphae and vesicles were observed (Table 2). More arbuscules were observed in sorghum roots from the MIP test, but arbuscules are difficult to observe in woody host species and counts were probably underestimated. Several non-mycorrhizal fungi produce hyphae and vesicles within root tissues. AM species identifications were beyond the scope of this study as spores were not collected.

When ornamental tree species were pooled within soil zone and contrasted, roots in BR soils were less colonized than roots in either HPR or CPM soils (Table 2). Means separations of arbuscules counted among sampled tree roots were not different for soil zone, tree species, or tree species within soil zone (Table 3 ). By contrast, both soil zone and tree species affected arbuscular colonization in sorghum roots from the MIP test (Table 3). The fewest arbuscules were produced in BR soils and soils in which $C$. florida were grown. All soils had AM capable of colonizing sorghum (Table 2).

When the regional soil zone interaction with tree species is considered for tree root tissues, neither arbuscule observations nor lack of observed fungal structures were affected. Similarly, in sorghum tissue samples, this interaction did not affect fields-of-view with no

Table 1. Trunk caliper, estimated years in production of field-grown ornamental trees, and soil test results of composite soil samples collected within the crop production rows of each ornamental cultivar at each nursery.

\begin{tabular}{|c|c|c|c|c|c|c|c|c|c|}
\hline Tree species & $\begin{array}{r}\text { Nursery soil } \\
\text { description }^{2}\end{array}$ & $\begin{array}{c}\text { Soil } \\
\text { zone }^{y}\end{array}$ & $\begin{array}{l}\text { Soil } \\
\mathrm{pH}\end{array}$ & $\begin{array}{l}\text { Soil } \\
\mathrm{P}^{\mathrm{x}}\end{array}$ & $\begin{array}{c}\mathrm{P} \\
\text { rate }^{\mathrm{w}}\end{array}$ & $\begin{array}{c}\text { Soil } \\
\mathrm{K}^{\mathrm{x}}\end{array}$ & $\begin{array}{c}\mathrm{K} \\
\text { rate }^{\mathrm{w}}\end{array}$ & $\begin{array}{c}\text { Years } \\
\text { in field }\end{array}$ & $\begin{array}{c}\text { Trunk caliper } \\
\pm \mathrm{SE}(\mathrm{n}=5)\end{array}$ \\
\hline \multicolumn{10}{|l|}{ Acer rubrum 'October Glory' } \\
\hline Laurels Nursery & Litz silt loam & $\mathrm{BR}$ & 4.7 & 20 & $\mathrm{H}$ & 87 & $\mathrm{H}$ & 3 & $36.4 \pm 2.0$ \\
\hline Fairview Tree Farm & Ashe loam & $\mathrm{BR}$ & 5.7 & 38 & $\mathrm{H}$ & 109 & $\mathrm{H}$ & 2 & $20.0 \pm 0.6$ \\
\hline Odom Nursery & Captina silt loam & HRP & 5.0 & 38 & $\mathrm{H}$ & 84 & $\mathrm{H}$ & 3 & $39.1 \pm 1.4$ \\
\hline Hawkersmith \& Son's Nursery & Dickson silt loam & HRP & 5.6 & 1 & $\mathrm{~L}$ & 61 & M & 4 & $70.9 \pm 3.5$ \\
\hline Little River Nursery & Waynesboro loam & CPM & 4.7 & 27 & $\mathrm{H}$ & 110 & $\mathrm{H}$ & 3 & $44.9 \pm 2.9$ \\
\hline Pleasant Cove Nursery & Waynesboro loam & CPM & 4.7 & 11 & M & 76 & $\mathrm{H}$ & 2 & $42.9 \pm 2.1$ \\
\hline \multicolumn{10}{|l|}{ Cornus florida 'Cherokee Princess' } \\
\hline Laurels Nursery & Dunmore silty clay loam & $\mathrm{BR}$ & 4.6 & $54+$ & $\mathrm{V}$ & 143 & $\mathrm{H}$ & 1 & $16.1 \pm 0.7$ \\
\hline Fairview Tree Farm & Ashe loam & $\mathrm{BR}$ & 4.5 & $54+$ & $\mathrm{V}$ & 93 & $\mathrm{H}$ & 1 & $19.5 \pm 1.9$ \\
\hline Odom Nursery & Captina silt loam & HRP & 4.9 & 27 & $\mathrm{H}$ & 81 & $\mathrm{H}$ & 2 & $29.5 \pm 3.1$ \\
\hline Hawkersmith \& Son's Nursery & Dickson silt loam & HRP & 7.1 & 47 & $\mathrm{H}$ & $145+$ & V & 4 & $33.5 \pm 3.3$ \\
\hline Little River Nursery & Waynesboro loam & CPM & 4.4 & $54+$ & V & $145+$ & V & 1 & $26.5 \pm 1.6$ \\
\hline Pleasant Cove Nursery & Waynesboro loam & CPM & 5.1 & 18 & $\mathrm{H}$ & 121 & $\mathrm{H}$ & 2 & $29.0 \pm 2.6$ \\
\hline \multicolumn{10}{|l|}{ Prunus serrulata 'Kwanzan' } \\
\hline Laurels Nursery & Litz silt loam & $\mathrm{BR}$ & 4.4 & $54+$ & V & $145+$ & $\mathrm{V}$ & 3 & $47.4 \pm 2.4$ \\
\hline Fairview Tree Farm & Ashe loam & $\mathrm{BR}$ & 5.1 & 38 & $\mathrm{H}$ & $145+$ & V & 3 & $35.0 \pm 0.9$ \\
\hline Odom Nursery & Captina silt loam & HRP & 4.8 & 8 & $\mathrm{~L}$ & 34 & $\mathrm{~L}$ & 4 & $53.2 \pm 2.0$ \\
\hline Hawkersmith \& Son's Nursery & Dickson silt loam & HRP & 6.0 & 18 & $\mathrm{H}$ & 94 & $\mathrm{H}$ & 3 & $33.0 \pm 1.6$ \\
\hline Little River Nursery & Waynesboro loam & CPM & 4.5 & 47 & $\mathrm{H}$ & 98 & $\mathrm{H}$ & 4 & $56.3 \pm 3.4$ \\
\hline Pleasant Cove Nursery & Waynesboro loam & CPM & 5.8 & 7 & $\mathrm{~L}$ & 111 & $\mathrm{H}$ & 3 & $38.4 \pm 0.2$ \\
\hline
\end{tabular}

${ }^{\text {z}}$ Soil classifications for each soil type are as follows: Ashe loam soils are classified as coarse-loamy, mixed, mesic, Typic Dystrochrepts; Captina silt loam soils are classified as fine-silty, siliceous, mesic Typic Fragiudults; Dickson silt loam soils are classified as fine-silty, siliceous, thermic Glossic Fragiudults, Dunmore silty clay loam soils are classified as clayey, kaolinitic, mesic Typic Paleudults; Litz silt loam soils are classified as loamy-skeletal, mixed, mesic Ruptic-Ultic Dystrochrepts; and Waynesboro loam soils are classified as fine, kaolinitic, thermic Typic Paleudults.

y Soil zones: $\mathrm{BR}=$ Blue Ridge, HRP = Highland Rim and Pennyroyal, CPM = Cumberland Plateau and Mountains

${ }^{\mathrm{x}}$ Soil $\mathrm{P}$ (phosphorus) and soil $\mathrm{K}$ (potassium) values are reported in kilograms per hectare.

${ }^{w} \mathrm{P}$ and $\mathrm{K}$ ratings indicate the relative availability of nutrients to plants; $(\mathrm{L})=$ low, $(\mathrm{M})=$ medium, $(\mathrm{H})=\mathrm{high},(\mathrm{V})=\mathrm{very}$ high.

${ }^{v}$ Years in field are estimates provided by nursery producers or foreman. 
Table 2. Comparisons of fungal structures observed among 100 microscopic fields-of-view among root samples of field-grown ornamental tree species and 'DeKalb DK40Y' sorghum root samples from the MIP test.

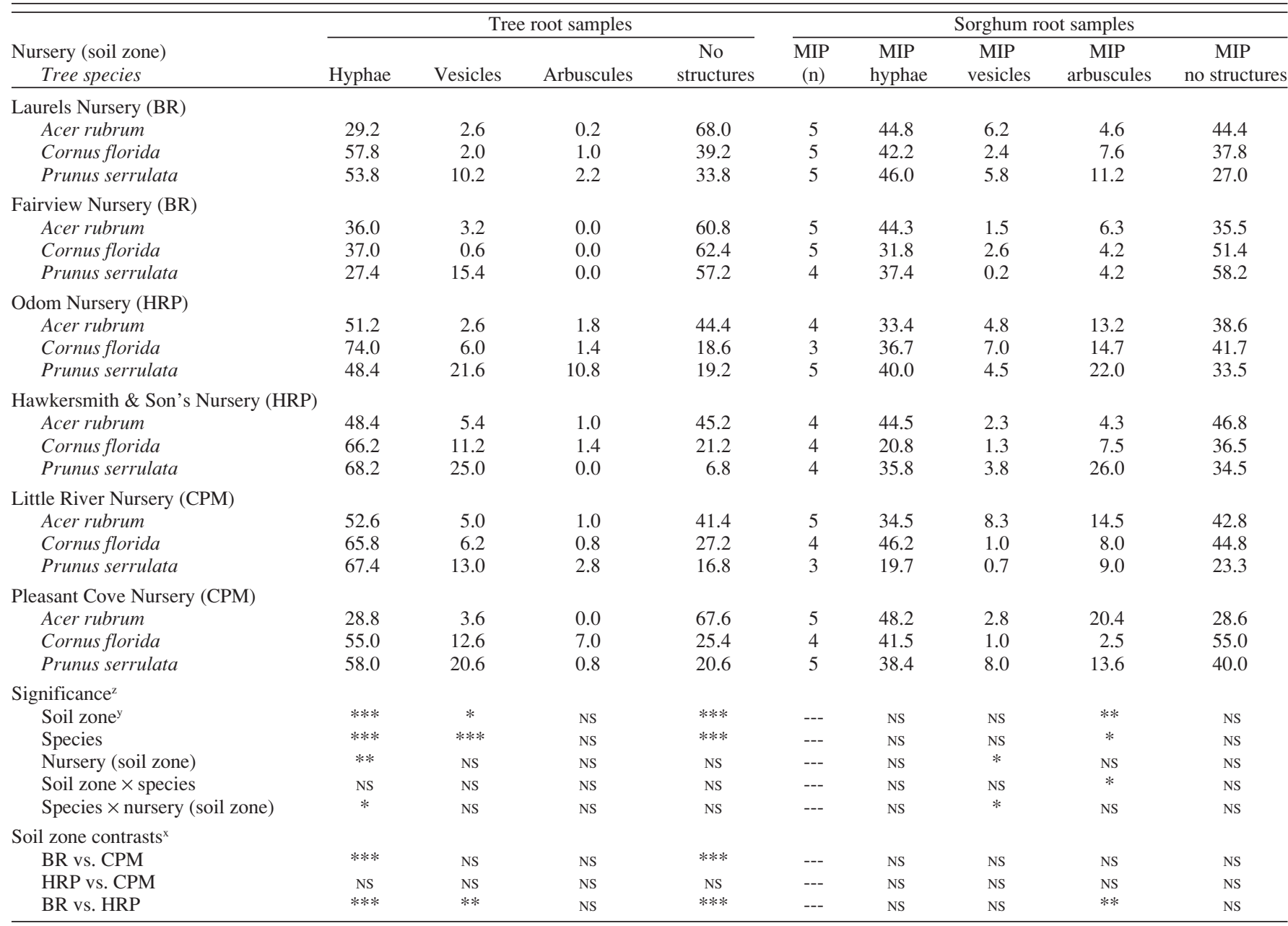

${ }^{2}$ A mixed ANOVA, with nurseries nested in soil zones, provided F tests $(P \leq 0.05)$ to determine significance of species, soil zone, and interaction effects on fungal structures observed among ornamental crop samples and the sorghum MIP test.

${ }^{y}$ Soil zone represents characteristics of the Blue Ridge (BR), Cumberland and Mountain Plateau (CPM), and Highland Rim and Pennyroyal (HRP) soil areas (USDANRCS, 2001).

${ }^{\mathrm{x}}$ Contrasts are generated from data pooled, within soil zones, among ornamental tree species from two nurseries.

Ns,,$* * * * * * *$ Nonsignificant or significant at $P \leq 0.05,0.01$, or 0.001 , respectively.

fungal structures. In sorghum roots, however, the regional soil zone interaction with tree species affected arbuscule numbers (Table 3 ). In the MIP test, AM fungi in BR soils produced the fewest arbuscules. Sorghum grown in HRP soils where 'Kwanzan' cherry trees were grown produced the most arbuscules. In CPM soils, sorghum grown in soils from red maple production areas had more arbuscules than sorghum from flowering dogwood soils, but not more than 'Kwanzan' cherry soils (Fig. 1). Finally, the interaction of tree species with regional soil zones did not influence AM fungal structures for either tree or sorghum root tissues (Table 2).

Nursery field soils differed in $\mathrm{pH}, \mathrm{P}$, and $\mathrm{K}$ concentrations (Table 1). Soils of $C$. florida 'Cherokee Princess' trees ranged from $\mathrm{pH} 4.4$ to 7.1 , while the range of soil $\mathrm{pH}$ in which $P$. serrulata 'Kwanzan' trees were grown was 4.4 to 6.0. Soil acidity was moderate in $A$. rubrum 'October Glory' production areas, ranging between 4.4 and 5.6. Soil $\mathrm{P}$ and $\mathrm{K}$ concentrations differed most among Prunus serrulata 'Kwanzan' trees (Table 1). C.florida
'Cherokee Princess' and A. rubrum 'October Glory' trees were grown in soils having medium to very high $\mathrm{P}$ and $\mathrm{K}$ levels. Soil temperatures, measured $22.9 \mathrm{~cm}$ deep during sampling, averaged $15 \pm 3^{\circ} \mathrm{C}\left(59 \pm 5^{\circ} \mathrm{F}\right)$ across all hosts and soil zones.

No consistent correlation of root colonization with soil $\mathrm{pH}, \mathrm{P}$, or $\mathrm{K}$ concentrations were apparent between fungal structures in field root samples and roots from the sorghum MIP test when all nurseries were combined (Table 4). Within the tree root samples, vesicles were more frequently observed with increasing soil $\mathrm{pH}$ and decreasing soil $\mathrm{P}$ concentrations. This correlation was not evident among sorghum root samples. In the MIP test with sorghum, more arbuscules were observed with low concentrations of soil P and K (Table 4). Regardless, AM fungi were active across a range of soil $\mathrm{P}$ and $\mathrm{K}$ concentrations and soil $\mathrm{pH}$ levels and may be attributed to more than one mycorrhizal species (Robson and Abbott, 1989). AM fungal species have demonstrated an adaptive capability for tolerating a range of soil acidity (Robson and Abbott, 1989).
Within nurseries, trunk caliper and fungal structures were not reliably correlated (Table 4). Hyphal observations in tree roots from Hawkersmith and Sons' and Pleasant Cove Nurseries showed a negative correlation with trunk caliper. This result is attributed to larger A. rubrum 'October Glory' trees, which had low numbers of hyphae observed among 100 fields-of-view (Table 2). Once planted, many field-grown trees in Tennessee are produced with relatively little soil disturbance. While some growers annually root-prune, growers often wait until the season preceding anticipated sale to root-prune trees with a subsoil Ublade (Garton, personal communication). The older maple trees in this study had correspondingly larger calipers, were of salable size, and would have been root-pruned to stimulate new root growth (Table 1). In theory, the inoculative potential of nursery soils where AM fungi are active would be greater where the largest numbers of young, fine roots exist and where soils are least disturbed. Under these conditions, higher inoculative potential would be expected to result from a greater abundance of 
Table 3. Means separations, by significantly different variables or interaction effects as determined by MIXED ANOVA, of arbuscules observed among 100 microscopic fields-of-view among root samples of field-grown ornamental tree species and 'DeKalb DK40Y' sorghum root samples from the MIP test.

\begin{tabular}{|c|c|c|c|c|c|}
\hline & \multicolumn{2}{|c|}{ Tree root samples } & \multicolumn{3}{|c|}{ Sorghum root samples } \\
\hline & Arbuscules & $\begin{array}{c}\text { No } \\
\text { structures }\end{array}$ & $\begin{array}{l}\text { MIP } \\
(\mathrm{n})\end{array}$ & $\begin{array}{c}\text { MIP } \\
\text { arbuscules }\end{array}$ & $\begin{array}{c}\text { MIP } \\
\text { No structures }\end{array}$ \\
\hline \multicolumn{6}{|l|}{ Soil zone } \\
\hline Highland Rim and Pennyroyal & 2.73 & $25.90 \mathrm{~b}$ & 5 & $14.60 \mathrm{a}$ & 38.59 \\
\hline Blue Ridge & 0.57 & $53.57 \mathrm{a}$ & 5 & $6.34 \mathrm{~b}$ & 42.38 \\
\hline Cumberland Plateau and Mountains & 2.07 & $33.17 \mathrm{~b}$ & 5 & $11.33 \mathrm{ab}$ & 39.08 \\
\hline $\operatorname{LSD}_{0.05}{ }^{\mathrm{z}}$ & \pm 2.40 & \pm 8.33 & & \pm 5.29 & \pm 10.22 \\
\hline$P>F^{\mathrm{y}}$ & NS & $* * *$ & & $* *$ & NS \\
\hline \multicolumn{6}{|l|}{$\underline{\text { Species }}$} \\
\hline Acer rubrum 'October Glory' & 0.67 & $54.57 \mathrm{a}$ & 5 & $10.53 \mathrm{ab}$ & 39.43 \\
\hline Cornus florida 'Cherokee Princess' & 1.93 & $32.33 \mathrm{~b}$ & 5 & $7.41 \mathrm{~b}$ & 44.53 \\
\hline Prunus serrulata 'Kwanzan' & 2.77 & $25.73 \mathrm{~b}$ & 4 & $14.33 \mathrm{a}$ & 36.09 \\
\hline $\operatorname{LSD}_{0.05}$ & \pm 2.40 & \pm 8.33 & & \pm 5.29 & \pm 10.22 \\
\hline$P>F$ & NS & $* * *$ & & $*$ & NS \\
\hline \multicolumn{6}{|l|}{$\underline{\text { Soil zone } \times \text { species }}$} \\
\hline \multicolumn{6}{|l|}{ Highland Rim and Pennyroyal $\times$ : } \\
\hline Acer rubrum 'October Glory' & 1.40 & 44.80 & 4 & $8.73 \mathrm{bc}$ & 42.68 \\
\hline Cornus florida 'Cherokee Princess' & 1.40 & 19.90 & 3 & $11.08 \mathrm{bc}$ & 39.08 \\
\hline Prunus serrulata 'Kwanzan' & 5.40 & 13.00 & 5 & $24.00 \mathrm{a}$ & 34.00 \\
\hline \multicolumn{6}{|l|}{ Blue Ridge $\times$ : } \\
\hline Acer rubrum 'October Glory' & 0.10 & 64.40 & 4 & $5.43 \mathrm{c}$ & 39.95 \\
\hline Cornus florida 'Cherokee Princess' & 0.50 & 50.80 & 3 & $5.90 \mathrm{c}$ & 44.60 \\
\hline Prunus serrulata 'Kwanzan' & 1.10 & 45.50 & 5 & $7.70 \mathrm{c}$ & 42.60 \\
\hline \multicolumn{6}{|c|}{ Cumberland Plateau and Mountains ×: } \\
\hline Acer rubrum 'October Glory' & 0.50 & 54.50 & 4 & $17.45 \mathrm{ab}$ & 35.68 \\
\hline Cornus florida 'Cherokee Princess' & 3.90 & 26.30 & 3 & $5.25 \mathrm{c}$ & 49.90 \\
\hline Prunus serrulata 'Kwanzan' & 1.80 & 18.70 & 5 & $11.30 \mathrm{bc}$ & 31.67 \\
\hline $\mathrm{LSD}_{0.05}$ & \pm 4.16 & \pm 14.42 & & \pm 9.15 & \pm 17.70 \\
\hline$P>F$ & NS & NS & & $*$ & NS \\
\hline
\end{tabular}

${ }^{\mathrm{z}}$ Where species effects on fungal structures were significant, LSD $(P \leq 0.05)$ was calculated from a pooled estimate, within each ornamental tree species or species-specific soil core, of all tree and sorghum root samples collected from each nursery and MIP test.

${ }^{y} \mathrm{~F}$ tests $(P \leq 0.05)$ were used to determine significance of variable and interaction effects using a MIXED ANOVA.

Ns, *,**,**** Nonsignificant or significant at $P \leq 0.05,0.01$ or 0.001 , respectively.

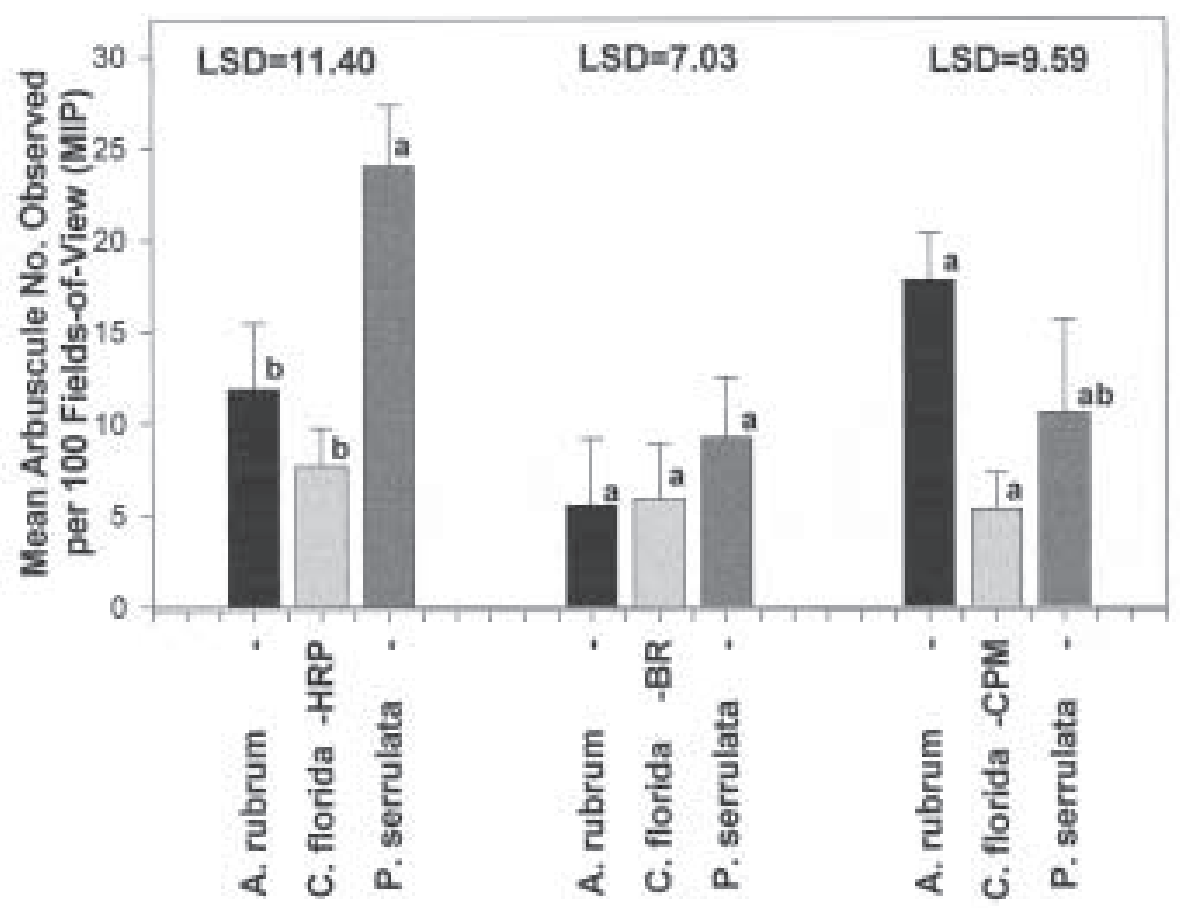

Fig. 1. Means separations $( \pm \mathrm{SE})$ for the Crop Species $\times$ Regional Soil Zone interaction, which were different by MIXED ANOVA $(P<0.05)$. Arbuscules were observed in root tissues of Sorghum bicolor 'DeKalb DK40Y' from the MIP test. Means accompanied by the same letter are not different $\left(\mathrm{LSD}_{0.05}\right)$. extraradicle hyphae or production of resting spores. Independently though, spore numbers in soil are an imperfect measure of the capability of AM fungi to inoculate host plants and are poorly correlated with soil colonization potential (Brundrett, 1991; Daniels et al., 1981; McGee, 1989). The results of our MIP test, which assessed soil inoculative potential using $S$. bicolor as a mycorrhizal trap crop, do not support a hypothesis of greater AM potential in soils surrounding older nursery stock. Among all nurseries, presence of fungal structures was not significantly correlated with trunk caliper. An exception that cannot be readily explained, found large numbers of arbuscules in sorghum roots to be positively correlated to trunk caliper of 2 -year-old ' $C$ herokee Princess' dogwoods grown at Pleasant Cove Nursery (Tables 1, 4).

In few instances were the fungal structures observed among tree roots correlated with the structures observed among $S$. bicolor roots from the MIP test. Among all nurseries, a negative correlation indicated fewer hyphae among sorghum samples than among roots of ornamental trees (Table 5). Several factors may confound these correlations. Sorghum seedlings were 10 weeks old and, in the greenhouse, were grown in warmer soils $\left(24 \pm 3{ }^{\circ} \mathrm{C}\right)$ than root samples gathered from the field (59 $\left.\pm 5^{\circ} \mathrm{F}\right)$. AM fungal activity is increased as temperature is elevated (Brundrett, 1991). Arbuscules and other fungal structures were more readily apparent in sorghum roots than in the tissues of the woody ornamental trees.

AM fungi are important plant-soil ecosystem components that provide a useful measure of relative soil quality and health. AM enhance soil quality, sustain biological productivity, increase rhizosphere diversity, and promote plant health (Bethlenfalvay, 1992; Kling and Jakobsen, 1998). In ornamental nurseries across Tennessee, AM fungal structures were recovered from each nursery soil and all ornamental tree root and sorghum root samples from the MIP test. No structures clearly identifiable as arbuscules were found among roots of the ornamental trees surveyed at Fairview Tree Farm. Results of the MIP test indicated, however, that AM fungi were active in soils from all three nursery-crop production areas at Fairview Tree Farm, were capable of colonizing S. bicolor, and formed structures including arbuscules that are characteristic of AM fungi (Table 2).

\section{Literature Cited}

Abbott, L.K. and A.D. Robson. 1991. Factors influencing the occurrence of vesicular-arbuscular mycorrhizas. Agr. Ecosyst. Environ. 35:121150

Augé, R.M., K.A. Schekel and R.L. Wample. 1987. Leaf water and carbohydrate status of VA mycorrhizal rose exposed to water deficit stress. Plant Soil 99:291-302.

Augé, R.M., A.J.W. Stodola, R.C. Ebel, and X. Duan. 1995. Leaf elongation and water relations of mycorrhizal sorghum in response to partial soil drying: two Glomus species at varying phosphorus fertilization. J. Expt. Bot. 46:297-307. Azcon-Aguilar, C. and J.M. Barea. 1996. Arbuscular 
Table 4. Correlation coefficients $(r)$ of fungal structures, which were observed among root samples of ornamental tree species and 'DeKalb DK40Y' sorghum root samples from the MIP test, with field-grown tree trunk calipers and soil test results.

\begin{tabular}{|c|c|c|c|c|c|c|c|c|}
\hline \multirow[b]{2}{*}{ Nursery } & \multicolumn{4}{|c|}{ Tree root samples } & \multicolumn{4}{|c|}{ Sorghum root samples } \\
\hline & Hyphae & Vesicles & Arbuscules & $\begin{array}{c}\text { No } \\
\text { structures }\end{array}$ & $\begin{array}{c}\text { MIP } \\
\text { hyphae }\end{array}$ & $\begin{array}{c}\text { MIP } \\
\text { vesicles }\end{array}$ & $\begin{array}{c}\text { MIP } \\
\text { arbuscules }\end{array}$ & $\begin{array}{c}\text { MIP } \\
\text { no structures }\end{array}$ \\
\hline \multicolumn{9}{|l|}{ All nurseries ${ }^{2}$} \\
\hline Soil phosphorus $(\mathrm{P})$ & 0.13 & $-0.25^{*}$ & -0.15 & 0.05 & -0.14 & -0.20 & $-0.25^{*}$ & -0.01 \\
\hline Soil potassium $(\mathrm{K})$ & 0.12 & -0.04 & -0.20 & -0.04 & -0.03 & -0.16 & $-0.26^{*}$ & 0.08 \\
\hline \multicolumn{9}{|l|}{ Trunk calipery } \\
\hline Odom Nursery & -0.43 & $0.52^{*}$ & 0.40 & -0.02 & 0.27 & -0.27 & 0.43 & -0.39 \\
\hline Hawkersmith \& Son's Nursery & $-0.52^{*}$ & $-0.52^{*}$ & 0.15 & $0.74^{* *}$ & 0.57 & -0.02 & -0.38 & 0.26 \\
\hline Little River Nursery & -0.17 & 0.31 & 0.14 & -0.01 & -0.40 & 0.36 & 0.30 & -0.49 \\
\hline Pleasant Cove Nursery & $-0.55^{*}$ & 0.01 & 0.04 & 0.33 & 0.32 & 0.22 & $0.80^{* * *}$ & $-0.65^{* *}$ \\
\hline
\end{tabular}

${ }^{2}$ Correlation coefficient values generated from combined observations of fungal structures among nurseries for either ornamental tree species or species-specific soil cores $(\mathrm{n}=79)$.

${ }^{y}$ For individual nurseries, correlation coefficient values generated from combined observations of fungal structures independent of ornamental tree species and species-specific soil cores $(n=15)$.

$*, * *, * * *$ Correlation coefficient values significant at $P \leq 0.05,0.01$, or 0.001 , respectively.

Table 5. Correlation coefficients $(r)$ of fungal structures, observed among root samples of ornamental tree species, with structures observed among 'DeKalb DK40Y' sorghum root samples from the MIP test.

\begin{tabular}{lcccc}
\hline $\begin{array}{l}\text { All nurseries } \\
(n=79)\end{array}$ & Hyphae & Vesicles & Arbuscules & $\begin{array}{c}\text { No } \\
\text { structures }\end{array}$ \\
\hline MIP hyphae & $-0.25^{*}$ & -0.11 & 0.08 & $0.24^{*}$ \\
MIP vesicles & 0.03 & -0.08 & -0.09 & 0.03 \\
MIP arbuscules & 0.05 & 0.20 & -0.03 & -0.12 \\
MIP no structures & 0.01 & 0.11 & 0.01 & -0.06 \\
\hline
\end{tabular}

${ }^{2}$ Correlation coefficient values are generated from observations of fungal structures combined among nurseries for either ornamental tree species or speciesspecific soil cores.

${ }^{*}$ Correlation coefficient values significant at $P \leq 0.05$.

mycorrhizas and biological control of soil-borne plant pathogens-An overview of the mechanisms involved. Mycorrhiza 6:457-464.

Bethlenfalvay, G.J. 1992. Mycorrhizae and crop productivity, p. 1-27. In: G.J. Bethlenfalvay and R.G. Linderman (eds.). Mycorrhizae in sustainable agriculture. Amer. Soc. Agron. Spec. Publ. No. 54. Madison, Wis.

Brechet, C. and F. le Tacon. 1984. Responses of endomycorrhizal and non-mycorrhizal plants of Acerpseudoplatanus to different levels of soluble and non-soluble phosphorus. Eur. J. For. Pathol. 14(2):68-77.

Brundrett, M. 1991. Mycorrhizas in natural ecosystems. Adv. Ecol. Res. 21:171-313.

Collins-Johnson, N. and F.L. Pfleuger. 1992. Vesicular-arbuscular mycorrhizae and cultural stress, p. 71-99. In: G.J. Bethlenfalvay and R.G. Linderman (eds.). Mycorrhizae in sustainable agriculture, Amer. Soc. Agron. Spec. Publ. No. 54. Madison, Wis.

Daniels, B.A., P.M. McCool, and J.A. Menge. 1981. Comparative inoculum potential of spores of six vesicular-arbuscular mycorrhizal fungi. New Phytol. 89:385-391.

Duan X, D.S. Neuman, J.M. Reiber, C.D. Green, A.M. Saxton, and R.M. Augé. 1996. Mycorrhizal influence on hydraulic and hormonal factors implicated in the control of stomatal con- ductance during drought. J. Expt. Bot. 47:15411550.

Hayman, D.S. 1982. Influence of soils and fertility on activity and survival of vesicular-arbuscular mycorrhizae. Phytopathol. 72:1119-1125.

Jakobsen, I. 1986. Vesicular-arbuscular mycorrhiza in field grown crops. III. Mycorrhizal infection and rates of phosphorus inflow in pea plants. New Phytol. 104:573-581.

Kling, M. and I. Jakobsen. 1997. Direct application of carbendazim and propiconazole at field rates to the external mycelium of three arbuscular mycorrhizal fungi: effect on ${ }^{32} \mathrm{P}$ transport and succinate dehydrogenase activity. Mycorrhiza 7:33-37.

Kling, M. and I. Jakobsen. 1998. Arbuscular mycorrhiza in soil quality assessment. Ambio 27(1):2933.

Larsen, J., I. Thingstrup, I. Jakobsen, and S. Rosendahl. 1996. Benomyl inhibits phosphorus transport but not alkaline phosphatase activity in a Glomus-cucumber symbiosis. New Phytol. 132:127-134.

McGee, P.A. 1989. Variation of propagule numbers of vesicular-arbuscular mycorrhizal fungi in semi-arid soil. Mycol. Res. 97:245-250.

McGonigle, T.P., M.H. Miller, D.G. Evans, G.L. Fairchild, and J.A. Swan. 1990. A new method which gives an objective measure of coloniza- tion of roots by vesicular-arbuscular mycorrhizal fungi. New Phytol. 115:495-501.

McGraw, A.-C. [sic] and N.C. Schenck. 1980. Growth stimulation of citrus, ornamental, and vegetable crops by select mycorrhizal fungi. Proc. Fla. State Hort. Soc. 93:201-205.

Miller, M.H., T.P. McGonigle, and H.D. Addy. 1995. Functional ecology of vesicular arbuscular mycorrhizas as influenced by phosphate fertilization and tillage in an agricultural system. Crit. Rev. Biotechnol. 15:241-255.

Morrison, S.J., P.A. Nicholl, and P.R. Hicklenton. 1993. VA mycorrhizal inoculation of landscape trees and shrubs growing under high fertility conditions. J. Environ. Hort. 11(2):64-71.

Reynolds, E.R.C. 1975. Tree rootlets and their distribution. In: J.G. Torrey and D.T. Clarkson (eds.). The development and function of roots. Academic, London.

Robson, A.D. and L.K. Abbott. 1989. The effect of soil acidity on microbial activity in soils, p. 139165. In: A.D. Robson (ed.). Soil acidity and plant growth. Academic Press Australia, Marrickville, N.S.W.

SAS Institute. 1985. SAS user's guide: Statistics. 5th ed. SAS Inst., Cary, N.C.

Soil Survey Division, Natural Resources Conserv. Serv., U.S. Dept. of Agr. Official soil series descriptions. [http://www.statlab.iastate.edu/ soils/osd] [Accessed 23 Mar 2001].

Spiess, S., S.D. Verkade, and G.E. Fitzpatrick. 1991. Effects of mycorrhizae on growth of Acer rubrum and Raphiolepis indica seedlings. Proc. Fla. State Hort. Soc. 104:290-291.

Sylvia, D.M. 1986. Effect of vesicular-arbuscular mycorrhizal fungi and phosphorus on the survival and growth of flowering dogwood (Cornus florida). Can. J. Bot. 64:950-954.

USDA-National Resources Conservation Service. 2001. MLRA soil survey region \#15. [http:// seweb.ga.nrcs.usda.gov/mlra15].

Wright, S.F. and A. Upadhyaya. 1998. A survey of soils for aggregate stability and glomalin, a glycoprotein produced by hyphae of arbuscular mycorrhizal fungi. Plant Soil 198(1):97-107. 